\title{
KOMODIFIKASI DALAM PENGEMBANGAN TRADISI OKOKAN SEBAGAI ATRAKSI WISATA DI DESA KEDIRI, TABANAN
}

\author{
I Wayan Windutama \\ Universitas Udayana \\ Email: windhu_utama@yahoo.com \\ I Nyoman Sunarta \\ Universitas Udayana \\ Email: cairns54@yahoo.com \\ NMS Wijaya \\ Universitas Udayana \\ Email: mdsofiawij@gmail.com
}

\begin{abstract}
This study aims to determine the forms of commodification in the development of the Okokan tradition as a tourist attraction in Kediri Village, Tabanan. The method used in this research is descriptive qualitative data collection techniques through observation, interviews, documentation, and literature study using a ladder of citizen participation theory, product life cycle theory, and commodification theory. This study found that the level of community participation was in the form of consultation with participation between the community and the government still being passive. While the stages of developing the Okokan tradition are at a stage of growth, where the wider community is getting to know Okokan with promotions carried out and proven by the appearance of the Okokan at various events. The forms of commodification in the development of the Okokan tradition as tourist attractions include the processes of production, distribution, and consumption.
\end{abstract}

Keywords: Community Participation, Okokan Tradition, Commodification, Kediri-Tabanan Village

\section{Pendahuluan}

Indonesia merupakan negara kepulauan yang terdapat banyak sekali daya tarik wisata yang banyak dikunjungi oleh wisatawan, dimana kunjungan wisatawan tersebut sebagai dorongan atau motivasinya yang mempunyai dampak pada sendisendi kehidupan masyarakat, antara lain: sosial ekonomi, sosial budaya, politik, dan 
lingkungan hidup. Di Indonesia sendiri memiliki beragam potensi kepariwisataan yang tersebar diberbagai daerah dan masing-masing memiliki keunggulannya tersendiri untuk dikembangkan. Salah satunya adalah potensi kepariwisataan Bali yang terkenal dengan sebutan "Pulau Dewata".

Agar pengembangan pariwisata dapat memberikan manfaat positif bagi pembangunan, maka dalam pelaksanaannya dibutuhkan strategi yang terencana dan sistematis bagi masyarakat. Keterlibatan atau partisipasi masyarakat menjadi penting dalam kaitannya dengan upaya keberlanjutan pariwisata dan pengelolaan potensi yang ada di daerahnya masing-masing dari berbagai aspek yang ada. Aspek kebudayaan yang meliputi tiga wujud (ideal, perilaku dan material) serta tujuh unsur pokok (sistem peralatan dan teknologi, sistem mata pencaharian, sistem kemasyarakatan, bahasa, kesenian, sistem pengetahuan, dan sistem religi), Koentjaraningrat (2009:221-229). Pada aspek kebudayaan khususnya tradisi masyarakat setempat merupakan salah satu potensi yang bisa dikembangkan sebagai atraksi wisata.

Salah satu tradisi yang dilakukan oleh masyarakat Desa Kediri, Kecamatan Kediri, Kabupaten Tabanan adalah Tektekan Kediri-Nangluk Merana atau lebih dikenal dengan tradisi Okokan merupakan suatu potensi wisata yang memiliki keunikan tersendiri. Tradisi Okokan merupakan tradisi yang hanya diadakan pada saat-saat tertentu yakni ketika terjadi wabah penyakit (gerubug) yang ada di Desa Kediri, yang bertujuan untuk menetralisir energi negatif atau menolak bala.

Semenjak tahun 2014, masyarakat Desa Kediri sudah menyepakati pelaksanaan tradisi Okokan untuk diadakan setiap tahunnya, yaitu menjelang hari raya Nyepi, tepatnya saat umat Hindu merayakan hari raya Pengerupukan. Karena pada saat hari raya Pengerupukan masyarakat setempat tidak ada yang membuat pawai atau parade ogoh-ogoh, melainkan diganti dengan pelaksanaan tradisi Okokan. Pelaksanaannya pun wajib diikuti oleh seluruh banjar di Desa Kediri yang 
terdiri dari lima banjar, yaitu: Banjar Jagasatru, Banjar Sema, Banjar Puseh, Banjar Delod Puri, dan Banjar Panti. Namun, juga diikuti oleh dua banjar lainnya yang tidak diwajibkan keikutsertaannya melainkan ikut memeriahkan yaitu: Banjar Pande dan Banjar Tanjung Bungkak karena secara administrasi berada di luar wilayah Desa Pakraman Kediri, (Aryawan, 2018).

Selain dilaksanakan saat menjelang perayaan hari raya Nyepi, Okokan juga kerap ditampilkan pada acara besar seperti Pesta Kesenian Bali (PKB), Festival Tabanan, Festival Tanah Lot, Festival Legian, Festival Sanur, peresmian patung Garuda Wisnu Kencana (GWK) tahun 2018, tampil pada acara Soundrenaline tahun 2018, kolaborasi dengan Banjar Gemeh Denpasar saat perayaan Pengerupukan 2019, bahkan pementasan Okokan sudah sampai ke luar daerah seperti Jawa Timur untuk memeriahkan acara festival budaya (Natha, 2017). Namun, dari kelima banjar yang ada di Desa Kediri hanya satu banjar yang kelihatan paling dominan dalam pengembangan tradisi Okokan yaitu Banjar Delod Puri. Karena Banjar Delod Puri satu-satunya banjar yang memiliki Sekaha Okokan tersendiri di luar dari organisasi adat, sedangkan banjar lainnya belum atau tidak memiliki Sekaha Okokan.

Perkembangan tradisi Okokan tidak merata ke semua banjar yang ada di Desa Kediri. Ketika ada acara yang menampilkan Okokan, maka yang biasa tampil untuk berpartisipasi adalah masyarakat dari Banjar Delod Puri dengan Sekaha Okokannya. Sedangkan dari banjar lain memiliki peluang yang kecil untuk ikut mewakili acara tersebut. Sehingga penelitian ini mengarah kepada tingkatan partisipasi masyarakat dalam pengembangan tradisi Okokan di Desa Kediri. Selain itu, juga membahas tahapan pengembangan tradisi Okokan sebagai atraksi wisata dan bentuk-bentuk komodifikasi dalam pengembangan tradisi Okokan sebagai atraksi wisata. 


\section{Teori dan Metode}

Penelitian ini menggunakan tiga teori teori, yaitu: teori Arnstein's (1969) a ladder of citizen participation, teori product life cycle, dan teori komodifikasi. Teori partisipasi menekankan adanya partisipasi masyarakat di dalam pembangunan agar menjadi model yang dipandang ideal bagi pengembangan suatu wilayah yang effisien. Partisipasi masyarakat menjadi model pengembangan bottom up yang sesuai bagi perencanaan suatu daya tarik wisata dalam mengidentifikasi tingkatan dan bentuk partisipasi masyarakat, yang dalam hal ini berkaitan dengan partisipasi masyarakat dalam pengembangan tradisi Okokan. Pendekatan teori partisipasi oleh Arnstein didasarkan atas delapan tingkatan yaitu: manipulation, therapy, informing, consultation, placation, partnership, delegated power dan citizen control, yang kemudian dibagi menjadi tiga kategori yaitu: nonparticpation, tokenism dan citizen power.

Teori product life cycle merupakan teori yang diterapkan dan digunakan dalam pengembangan suatu produk yang dikenal dengan teori siklus hidup produk yang dipopulerkan oleh Levitt (1978). Dimana menggambarkan riwayat produk sejak diperkenalkan ke pasar sampai dengan ditarik dari pasar yang memiliki penggolongan ke dalam empat tahapan yaitu: tahap perkenalan (introduction), tahap pertumbuhan (growth), tahap kedewasaan (maturity), dan tahap kemunduran (decline), Basu Swastha (1984:127-132) dalam Hidayati (2011). Dalam hal ini yang dimaksudkan sebagai produk adalah tradisi Okokan. Karena pada dasarnya produk pariwisata merupakan suatu bentukan yang nyata (tangible product) dan tidak nyata (intangible product), sehingga unsur budaya yang ada di dalam Okokan tersebut bisa dijadikan suatu produk yang bisa dijual kepada masyarakat luas khususnya wisatawan untuk dijadikan sebagai atraksi wisata. Disini lah, teori product life cycle digunakan untuk melihat tahapan dalam pengembangan tradisi Okokan sebagai atraksi wisata. 
Teori komodifikasi digunakan dalam membahas perkembangan pariwisata yang terjadi berpengaruh terhadap kebudayaan masyarakat setempat. Dengan berkembangnya turisme dan industri pariwisata, keberadaan kesenian tradisional saat ini telah menjadi bagian dari komersialisasi budaya sebagai produk. Adanya komersialisasi dalam industri pariwisata ini lah, muncul suatu gejala yang dinamakan komodifikasi kebudayaan, Karl Marx dan George Simnel, dalam Prayogi (2012). Menyangkut komodifikasi, perubahan bentuk kebudayaan ini dilakukan dengan cara menjadikan tradisi Okokan sebagai atraksi wisata untuk bisa dipertontonkan dan diperjual belikan kepada wisatawan yang waktu kunjungan umumnya sangat terbatas. Sehingga bersamaan dengan terjadinya proses komodifikasi pada tradisi Okokan, yang meliputi proses produksi, distribusi, dan konsumsi yang menyebabkan terjadinya pergeseran makna terhadap keaslian atau otentik dari tradisi Okokan tersebut.

Penelitian ini merupakan jenis penelitian menggunakan analisis deskriptif kualitatif dengan data yang diperoleh bersumber dari data primer maupun data sekunder dan didukung dengan data yang didapatkan melalui observasi, wawancara mendalam, dokumentasi, dan studi kepustakaan. Pengambilan sample dilakukan dengan menggunakan teknik purposive sampling, dengan jumlah informan sebanyak enam orang yang terdiri dari Kepala Perbekel Desa Kediri dan kelian adat dari masing-masing banjar yang ada di Desa Kediri, yang dianggap mengetahui akan perkembangan tradisi Okokan.

\section{Gambaran Umum Desa Kediri}

Luas wilayah Desa Kediri, 459 Ha atau sekitar 0,5\% luas Kabupaten Tabanan. Secara administratif Desa Kediri terbagi atas 2 (dua) Desa Pakraman dan 7 (tujuh) Banjar Dinas/Dusun, yaitu: Desa Pakraman Kediri dan Desa Pakraman Demung. Khusus untuk Desa Pakraman Kediri terdiri dari 5 (lima) Banjar Adat/Banjar antara lain: 1) Banjar Jagasatru, 2) Banjar Sema, 3) Banjar Puseh, 4) Banjar Delod Puri, dan 
5) Banjar Panti. Keseluruhan jumlah penduduk Desa Kediri sebanyak 9.965 orang yang terdiri dari jumlah penduduk laki-laki sebanyak 5.026 orang dan perempuan sebanyak 4.940 orang, dengan jumlah Kepala Keluarga yang ada sebanyak 2.703 orang (Kantor Perbekel Desa Kediri, 2019).

Desa Kediri memiliki infrastruktur jalan yang sangat memadai dan bisa diakses dengan berbagai macam kendaraan bermotor seperti sepeda motor, mobil, hingga bus sekalipun. Hal ini dikarenakan jalur yang melalui Desa Kediri adalah jalur pariwisata Tabanan-Tanah Lot sehingga kualitas jalannya baik.

Desa Kediri memiliki kekuatan historis dan erat kaitannya dengan kepahlawanan Raja Tabanan. Sejarah Desa Kediri juga tidak terlepas dari keberadaan Pura Tanah Lot yang dibuktikan dengan adanya peninggalan Keris Ki Baru Gajah yang hingga sekarang masih disimpan dan disakralkan di Puri Kediri. Sehingga hal tersebut merupakan keunikan yang dimiliki Desa Kediri untuk dijadikan sebagai daya tarik wisata. Adapun daya tarik tersebut meliputi: Puri Kediri, Pura Desa Lan Puseh Kediri, dan Tanah Lot.

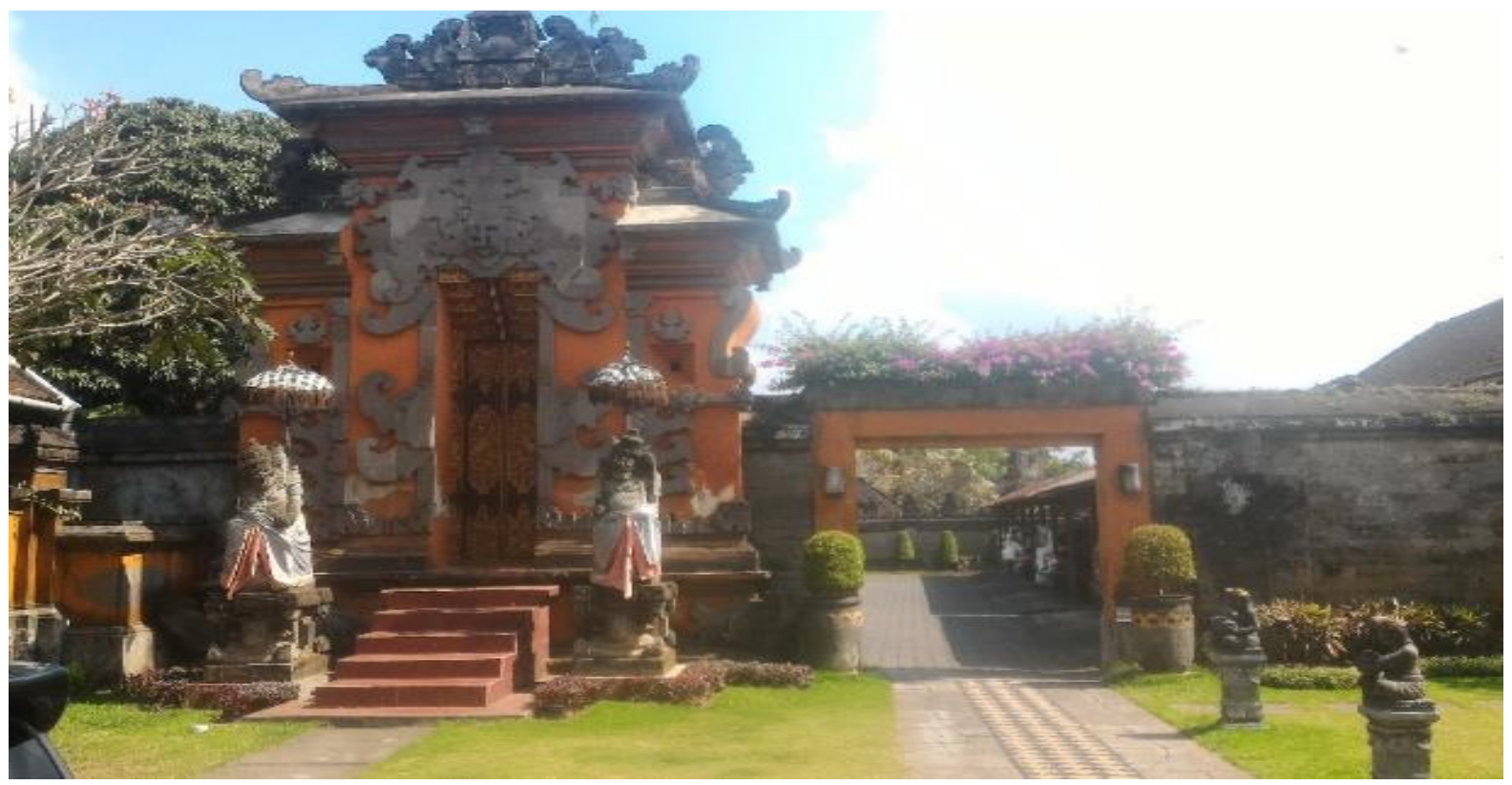

Gambar 1. Puri Kediri

Sumber: Penulis (2019) 


\section{Partisipasi Masyarakat Desa Kediri dalam Pengembangan Tradisi Okokan}

Partisipasi masyarakat yang ada di Desa Kediri sampai saat ini baru sebatas untuk menjaga dan melestarikan tradisi yang berkembang di masyarakat lokal yakni tradisi Okokan dengan ikut berpartisipasi di dalam pementasannya. Karena di dalam pementasan tradisi Okokan memerlukan peran serta banyak orang untuk partisipasi, mulai dari kalangan anak-anak, pemuda/i, dewasa, hingga partisipasi ibu-ibu PKK dalam memainkan alat musik Okokan atau tek-tekan yang jumlahnya cukup banyak.

Berdasarkan dari hasil observasi di lapangan menunjukan belum ada partisipasi aktif yang dilakukan oleh masyarakat terkait pengembangan tradisi Okokan sebagai atraksi wisata. Selain peran serta dan ikut berpartisipasi pada saat pementasan tradisi Okokan, peran masyarakat juga terlihat di dalam proses pembuatan Okokan. Mata pencaharian beberapa kepala keluarga yang ada di Desa Kediri yang jumlahnya tidak terlalu banyak di masing-masing banjar adalah sebagai pengerajin Okokan. Pembuatan Okokan tersebut dilakukan di rumah mereka sendiri sesuai dengan pesanan yang diinginkan, dengan proses pengerjaan untuk satu Okokan sampai selesai memerlukan waktu paling cepat dua minggu hingga satu bulan lamanya, dengan kisaran harga untuk satu Okokan yaitu Rp 3.000.000 hingga $\operatorname{Rp} 4.000 .000$.

Selain sebagai pengerajin atau pembuat Okokan, beberapa masyarakat Desa Kediri ada yang bermatapencaharian sebagai pembuat patung Okokan. Patung tersebut berbentuk orang yang sedang memainkan Okokan dengan ciri khas masyarakat Desa Kediri yaitu Okokan yang dimainkan dengan dua orang dan dibantu dengan sebilah bambu untuk memikul Okokan tersebut. 


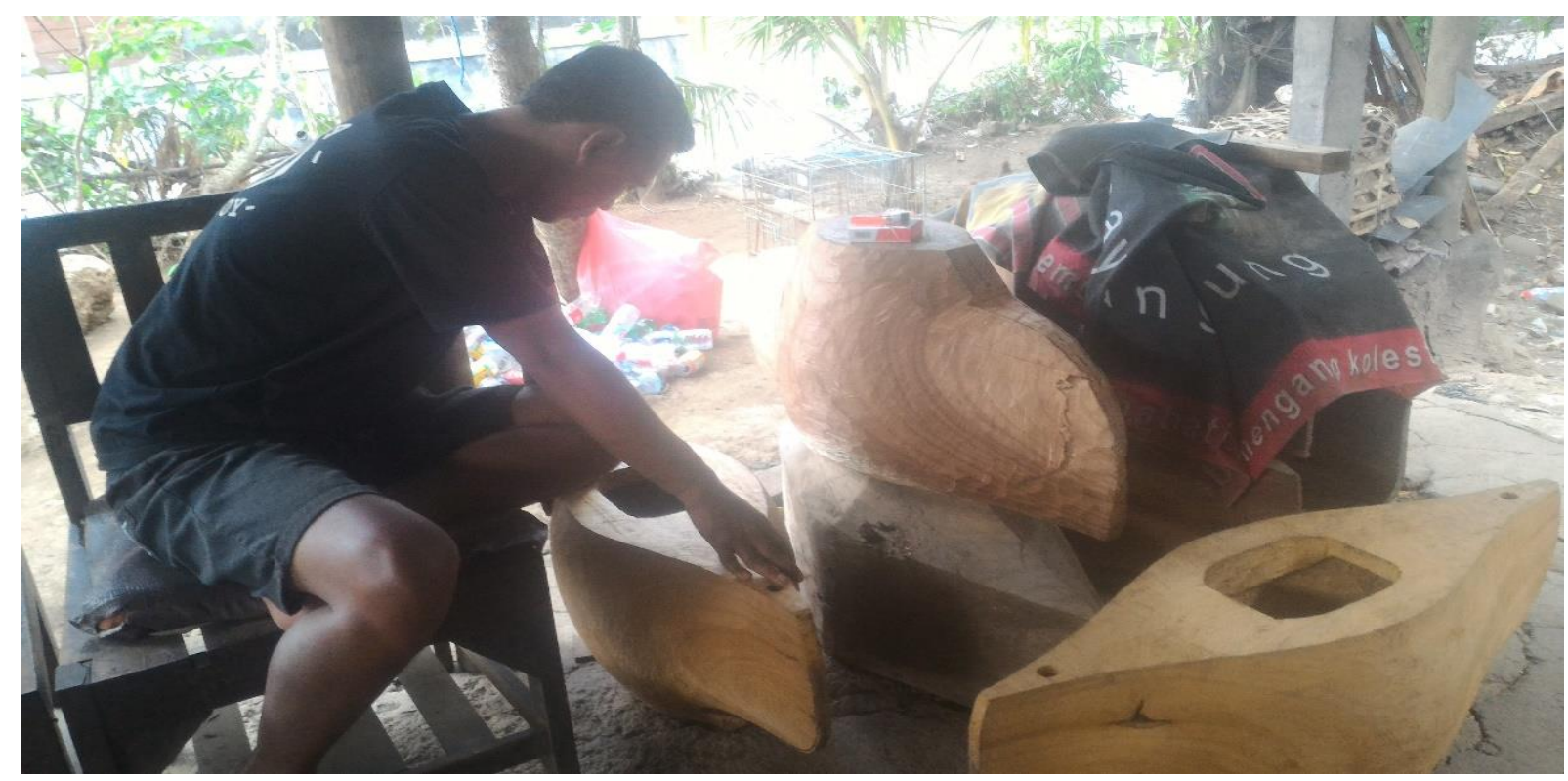

Gambar 2. Proses Pembuatan Okokan

Sumber: Penulis (2019)

\section{Tingkatan Partisipasi Masyarakat Desa Kediri dalam Pengembangan Tradisi Okokan Berdasarkan Teori A Ladder of Citizen Participation}

Berdasarkan teori partisipasi masyarakat yang dikemukakan oleh Arnstein atau yang lebih dikenal dengan Teori A Ladder of Citizen Participation yang memiliki delapan bentuk tingkatan dari anak tangga partisipasi. Maka dapat dikatakan Okokan yang ada di Desa Kediri termasuk kedalam bentuk tingkatan Consultation. Bentuk consultation tersebut merupakan suatu bentuk yang menggambarkan dimana partisipasi yang terjadi masih bersifat semu dan hanya berupa pencitraan. Pada tahap ini komunikasi yang terjadi telah bersifat dua arah, tapi masih bersifat partisipasi yang semu. Sudah ada penjaringan aspirasi, telah ada aturan pengajuan usulan, dan telah ada harapan bahwa aspirasi masyarakat akan didengarkan, tapi belum ada jaminan apakah aspirasi tersebut akan dilaksanakan ataupun perubahan akan terjadi. Pada tahap ini masyarakat tidak hanya diinformasikan namun lebih jauh ada kegiatan konsultasi antara pemerintah dan masyarakat. 
Semenjak disepakati bersama berkaitan dengan Okokan diadakan setiap tahunnya mulai dari tahun 2014 hingga kini, sekaligus dengan sudah ada dikukuhkannya satu Sekaha Okokan yang ada di Desa Kediri oleh Bupati Tabanan. Dalam perjalanannya juga mendapatkan keputusan bersama untuk membuat wantilan Pura Desa Lan Puseh Kediri yang nantinya akan dijadikan tempat pementasan Okokan khusus untuk wisatawan yang datang berkunjung ke Desa Kediri. Namun, sampai saat ini ide dan gagasan tersebut masih dipertanyakan dan belum terealisasikan yang kendalanya tidak terlepas dari belum adanya anggaran dan faktor lainnya. Meskipun Okokan sudah rutin dipentaskan setiap tahunnya tetapi masih dikembangkan oleh masyarakat Desa Kediri untuk nantinya menjadi atraksi wisata dengan mementaskan Okokan sesuai dengan permintaan tamu yang datang ke Desa Kediri di tempat khusus yaitu wantilan Pura Desa Lan Puseh Kediri sebagai stage nya.

Bentuk tingkatan consultation termasuk dalam kategori degree of tokenism yang artinya adanya partisipasi dari masyarakat belum maksimal yang hanya sebatas pada keikutsertaan dengan belum memiliki kekuatan untuk melaksanakan ide dan gagasan yang dimiliki. Sehingga hal tersebut menjadikan partisipasi dari masyarakat yang pasif. Pada kenyataannya ide dan gagasan yang dimiliki susah untuk diwujudkan akibat keterbatasan yang ada, baik berupa keterbatasan wewenang ataupun permodalan serta kemampuan dari masyarakat itu sendiri. Hal ini akan berdampak pada manfaat yang diterima masyarakat cenderung kepada mereka yang terlibat langsung dengan kegiatan di dalamnya seperti mereka yang menjadi anggota, mewakili, atau menjadi peserta dalam pelaksanaan Okokan. Partisipasi yang bersifat semu dimana masyarakat yang sudah memiliki rencana pengembangan Okokan dengan partisipasi aktif dari masyarakat kedepannya, namun dari segi pemerintah hanya melihat kesuksesan dari industri pariwisata tanpa memberikan program dari pemerintah langsung. 


\section{Partisipasi Masyarakat dan Tahap Pengembangan Tradisi Okokan Menjadi} Atraksi Wisata Berdasarkan Teori Product Life Cycle

Desa Kediri yang memiliki tradisi unik yakni dengan adanya tradisi Okokan, pada awalnya tradisi tersebut merupakan tradisi yang dilaksanakan untuk menetralisir energi negatif yang ada di desanya. Biasanya tradisi Okokan baru akan dilaksanakan ketika Desa Kediri sedang mengalami musibah (gerubug) atau terserang wabah penyakit (kebrebehan) dengan masing-masing banjar yang ada mengelilingi desa dengan membunyikan bunyi-bunyian (nek-tek atau tek-tekan) yang lebih dikenal dengan tradisi Okokan. Waktu dalam pementasan Okokan sendiri tidak tentu dan bahkan dalam kurun waktu lima tahun belum tentu akan dilaksanakan kalau desa tidak mengalami kebrebehan. Wabah penyakit yang terjadi biasanya bermacam-macam, mulai dari gagal panen yang dialami para petani hingga penyakit yang menyerang masyarakat desa dari segala usia yang penyebabnya juga tidak jelas dan bahkan ada masyarakat yang meninggal dunia tanpa sebab yang pasti.

Untuk pertama kalinya pelaksanaan tradisi Okokan di Desa Kediri rutin diadakan setiap tahunnya dimulai dari tahun 2014 hingga sekarang ini melalui musyawarah yang melibatkan semua kalangan masyarakat di masing-masing banjar yang ada di Desa Kediri. Dengan istilah Tek-tekan Kediri (Nangluk Merana) yang wajib diikuti oleh semua banjar yang ada di Desa Kediri. Selain itu, kini Okokan juga telah dipentaskan di berbagai event seni seperti Festival Tabanan, Festival Tanah Lot, Festival Legian, Festival Sanur, pertemuan Interpol, Pesta Kesenian Bali (PKB), peresmian patung Garuda Wisnu Kencana (GWK) tahun 2018, Soundrenaline tahun 2018, hingga yang terakhir berkolaborasi dengan Sekaha Teruna Banjar Gemeh Denpasar dalam pawai ogoh-ogoh Kota Denpasar tahun 2019. 


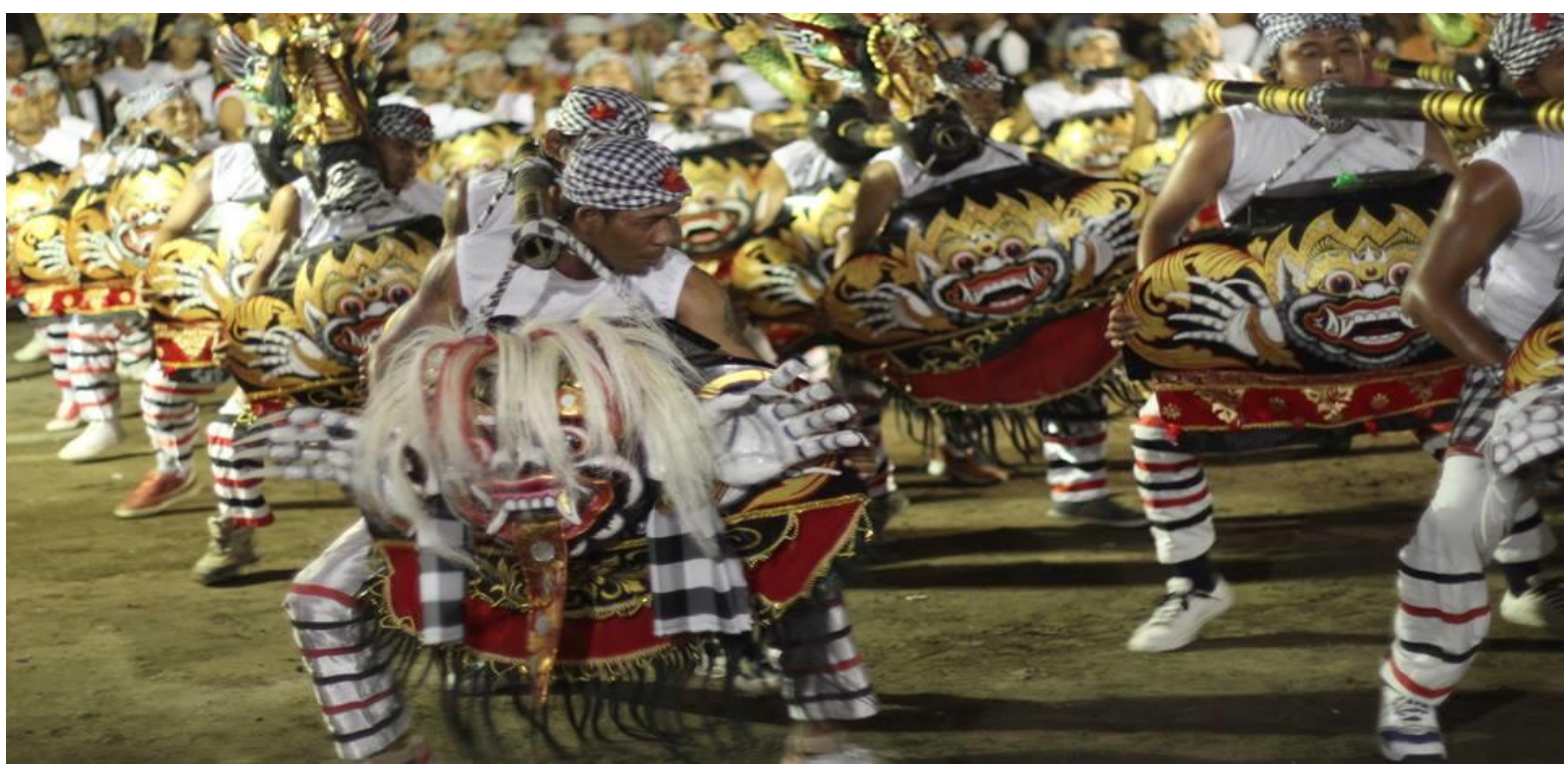

Gambar 3. Tradisi Okokan Kediri

Sumber: Penulis (2019)

Berdasarkan teori yang digunakan untuk membahas tahapan atau fase sejauh mana pengembangan tradisi Okokan untuk dijadikan sebagai atraksi wisata, jika dikaitkan dengan teori Product Life Cycle yang dipopulerkan oleh Levitt (1978), maka tradisi Okokan di Desa Kediri sudah memasuki fase pertumbuhan (growth) yang sudah didukung dengan beberapa fasilitas penunjang pariwisata yang dipersiapkan. Dimana konsumen yang dalam hal ini adalah wisatawan mulai mengenal produk yang dibuat yakni Okokan yang tentunya dibarengi dengan promosi yang dilakukan. Terbukti dengan banyaknya undangan dari berbagai pihak yang ingin menampilkan Okokan dalam berbagai event khususnya yang berkaitan dengan kesenian dan kebudayaan. Seluruh partisipasi dalam pementasan Okokan memang sepenuhnya melibatkan masyarakat lokal dari masing-masing banjar yang ada di Desa Kediri. Hal tersebut bisa dilihat dari pementasan Okokan setiap tahunnya di Desa Kediri yang wajib diikuti oleh semua banjar yang ada di Desa Kediri. Meskipun dari masing-masing banjar tersebut belum sepenuhnya memiliki Sekaha Okokan, namun partisipasi masyarakat yang ikut adalah berdasarkan krama adat masing-masing banjar. Sedangkan banjar yang sudah memiliki Sekaha Okokan tersendiri di luar organisasi adat adalah Banjar Delod Puri yang sudah disahkan oleh 
Dinas Kebudayaan dan Pariwisata Kabupaten Tabanan dan Banjar Jagasatru yang belum disahkan. Banjar Delod Puri merupakan banjar yang paling menonjol di dalam pengembangan dan pementasan Okokan pada berbagai event yang menampilkan Okokan dengan Sekaha Okokannya.

\section{Bentuk-bentuk Komodifikasi dalam Pengembangan Tradisi Okokan sebagai Atraksi Wisata}

Berdasarkan atas hasil penelitian di lapangan, bentuk-bentuk komodifikasi tradisi Okokan sebagai atraksi wisata di Desa Kediri meliputi Kediri meliputi proses produksi, distribusi, dan konsumsi yang dijelaskan sebagai berikut:

\section{Proses Produksi}

Komodifikasi tradisi Okokan dalam proses produksi dapat dilihat pada komodifikasi jadwal pementasan dan tata penyajian. Adanya komodifikasi jadwal pementasan dapat dilihat dari pementasan tradisi Okokan yang saat ini telah menjadi sebuah pementasan yang dilaksanakan secara teratur dan terjadwal.

Sebelum dikembangkan dan dikemas sebagai produk wisata, Okokan awalnya hanya dipentaskan pada waktu tertentu saja yakni ketika masyarakat desa diserang wabah penyakit (gerubug) dan pelaksanaannya juga tidak untuk dipertunjukan. Namun, semenjak tahun 2014 hingga sekarang ini pelaksanaan Okokan rutin diadakan setiap tahunnya di Desa Kediri yang puncaknya pada Hari Raya Pengerupukan. Hal tersebut ditetapkan pada peraturan tidak tertulis berdasarkan hasil musyawarah desa yang dihadiri oleh tokoh adat dari masing-masing banjar seDesa Kediri dan disetujui oleh seluruh banjar.

Komodifikasi dari tata penyajian dalam pementasan tradisi Okokan dapat dilihat dari segi pemakaian kostum para pemain dan penarinya. Pada awalnya kostum pemain Okokan masih sederhana dengan hanya menggunakan kain bernuansa hitam putih (poleng) dan bertelanjang dada. Namun, kini sudah menggunakan 
pakaian dengan desain modern tetapi tetap bernuansakan poleng sebagai ciri khas masyarakat Hindu. Sedangkan kostum penari sudah mengikuti perkembangan zaman yang modern sesuai dengan tema tarian yang akan dibawakan dan ditentukan oleh desa sebelumnya sebagai tema yang akan di pakai tiap tahunnya.

Adanya penambahan peralatan yang digunakan dalam Okokan juga menambah komodifikasi dari tata penyajian. Penambahan peralatan tersebut seperti contohnya bedug, tempeh, ceng-ceng, gong, dan bahkan hingga menambahkan gambelan baleganjur untuk dikolaborasikan dengan Okokan agar lebih menarik untuk disaksikan.

\section{Proses Distribusi}

Dalam proses distribusi, tradisi Okokan juga mengalami komodifikasi pada promosi. Akibat semakin berkembangnya komodifikasi Okokan menjadi produk yang dikomersialisasikan untuk pariwisata, juga turut memberikan pergeseran terhadap penyebaran informasi dari pelaksanaan Okokan itu sendiri.

Sebelum dikemas menjadi produk wisata, pelaksanaan Okokan yang dilakukan oleh para praktisi tidak pernah dipromosikan bahkan sangat enggan menunjukkan eksistensinya dalam masyarakat. Masyarakat cenderung mengetahui informasi tentang keberadaan Okokan dari mulut ke mulut yang beredar dalam masyarakat. Setelah dikemas dan dikomersialisasikan menjadi atraksi wisata, saat ini keberadaan Okokan sudah mulai dilakukan promosi melalui berbagai media dengan menonjolkan keunggulan-keunggulan dari Okokan. Seperti yang dilakukan oleh Sekaha Okokan dari Banjar Delod Puri yang mempromosikan Okokan melalui media elektronik seperti khususnya yang berbasis internet diantaranya melalui website dan sosial media facebook. 


\section{Proses Konsumsi}

Komodifikasi tradisi Okokan dari sisi konsumsi dapat dilihat dari adanya komodifikasi fungsi pementasan dan tempat pementasan. Pada awalnya fungsi tradisi Okokan adalah sebagai tradisi penolak bala atau penetralisir energi negatif secara niskala dan untuk menghilangkan wabah penyakit yang ada di Desa Kediri. Kini telah beralih fungsi menjadi orientasi ekonomi dengan adanya harga atau tarif tertentu, semenjak Okokan dijadikan atraksi wisata komersial yang dipentaskan dalam berbagai event dengan menampilkan Okokan.

Selain dipentaskan di desa sebagai tradisi, bahkan pementasan Okokan telah sampai ke luar desa untuk ditampilkan dan dikolaborasikan dengan musik lainnya. Seperti ditampilkan saat Pesta Kesenian Bali (PKB), Festival Tabanan, Festival Tanah Lot, Festival Legian, Festival Sanur, peresmian patung Garuda Wisnu Kencana (GWK) tahun 2018 sebagai penyambutan, tampil pada acara Soundrenaline 2018, hingga terakhir kolaborasi dengan Banjar Gemeh Denpasar saat perayaan Pengerupukan tahun 2019. Bahkan pementasan Okokan sudah sampai ke luar daerah seperti Jawa Timur untuk memeriahkan acara seperti festival budaya.

Komodifikasi dari sisi tempat pementasan tradisi Okokan dimana pada awalnya diadakan di depan Pura Desa lan Puseh Kediri yang selanjutnya dengan mengelilingi desa. Sebelum terjadi komodifikasi menjadi daya tarik wisata, pelaksanaan Okokan tidak memiliki penataan tempat yang bersifat komersial. Serta tampilan tempat pelaksanaannya tidak menjadi prioritas bagi masyarakat. Kini, telah bergeser dengan rencana pembuatan wantilan Pura Desa lan Puseh Kediri yang direncanakan sebagai lokasi dilaksanakannya pementasan Okokan. Hal tersebut telah dianggarkan dan ditargetkan akan mulai dibangun pada tahun 2020 mendatang oleh Desa Kediri. Sebagai langkah awal akan dibangun wantilan yang sebagai tempat pertunjukan Okokan untuk wisatawan yang datang ke Desa Kediri. Setelahnya baru akan memulai dengan menyusun paket wisata untuk Desa Kediri 
dengan memanfaatkan potensi lokal yang ada yakni mulai dari Pura Desa Lan Puseh Desa Kediri dan Puri Kediri.

\section{Simpulan dan Saran}

Berdasarkan pembahasan dari hasil analisis data, adapun simpulan yang dapat diambil adalah 1) Tingkatan partisipasi masyarakat Desa Kediri dalam pengembangan tradisi Okokan termasuk ke dalam bentuk tingkatan consultation. Pada tahapan tersebut bermakna bahwa ide dan gagasan yang sudah dimiliki oleh masyarakat belum tersampaikan dan terealisasikan yang kendalanya tidak terlepas dari belum adanya anggaran, dukungan pemerintah, dan faktor lainnya dari masyarakat. 2) Tahapan pengembangan tradisi Okokan sebagai atraksi wisata berada pada fase pertumbuhan (growth). Dimana masyarakat luas khususnya wisatawan mulai mengenal Okokan yang dibarengi dengan promosi yang dilakukan, terbukti dengan ditampilkannya Okokan dalam berbagai event. 3) Dalam pengembangan tradisi Okokan sebagai atraksi wisata, telah terjadi komodifikasi didalamnya, dengan bentuk-bentuk komodifikasi meliputi proses produksi, konsumsi, dan distribusi.

Adapun saran yang dapat dikemukakan yaitu: 1) Pemerintah Desa Kediri sebagai lembaga yang memiliki kekuasaan di desa harus bisa memfasilitasi aspirasi dari masyarakat lokal dengan. membuatkan kebijakan pemerataan kepada seluruh banjar yang ada terkait pengembangan Okokan sebagai atraksi wisata dengan Okokan sebagai ikon Desa Kediri. Seperti dengan cara membuat sekaha Okokan mengatas namakan Desa Kediri yang merupakan perwakilan anggota dari masingmasing banjar yang ada untuk pemerataan 2) Lembaga desa dan masyarakat dalam pengembangan tradisi Okokan sebagai atraksi wisata harus lebih tegas dalam membatasi perubahan-perubahan yang dapat menghilangkan ciri khas atau keaslian dari Okokan. Sehinggga keberadaan tradisi Okokan akan tetap terjaga dengan pengembangan yang dilakukan mulai mengarah kearah yang lebih modern saat ini. 
Agar tidak lepas dari unsur kebudayaan masyarakat setempat khususnya dalam kaitannya sebagai masyarakat hindu.

\section{Daftar Pustaka}

Arnstein, Sherry. R. (1969). A ladder of citizen participation. Journal of the American Institute of Planners, 35, 216-224.

Hidayati, Siti Nur. 2011. Kajian Teoritis Mengenai Incremental Value-Relevance Informasi Laba Dan Arus Kas Dengan Mempertimbangkan Siklus Hidup Perusahaan. Jurnal. Universitas Muhammadiyah Semarang.

Koentjaraningrat. 2009. Ilmu Antropologi. Jakarta: Rineka Cipta.

Layola, Lusiana, Edi Suarto, Ade Irma Suryani. 2017. Partisipasi Masyarakat dalam Pengembangan Daya Tarik Objek Wisata Musiduga di Kecamatan Sijunjung Kabupaten Sijunjung. Jurnal. Sekolah Tinggi Keguruan dan Ilmu Pendidikan (STKIP) PGRI Sumatera Barat.

Lestari, Julita. 2018. “Tradisi Malape Baka di Kenagarian Sungai Tunu Kecamatan Ranah Pesisir Kabupaten Pesisir Selatan" (skripsi). Padang: Universitas Islam Negeri.

Lestari, Sri Dwi. 2014. Komodifikasi Dramatari "Cak Ramayana" Desa Singapadu Dalam Industri Pariwisata. Jurnal. JUMPA Jurnal Magister Pariwisata, Universitas Udayana.

Natha, A.A. Ngr. Gd. Agung Wira Loka. 2017. Tradisi Okokan Sebagai Bahan Ajar dalam Pembelajaran Bahasa Bali Di SMP dan SMA/SMK. Jurnal. Fakultas Dharma Acarya, Institut Hindu Dharma Negeri Denpasar.

Nawawi, H. Hadari. 1992. Instrumen Penelitian di Bidang Sosial. Yogyakarta: Gadjah Mada University Press.

Pitana, I Gde dan I Ketut Surya Diarta. 2009. Pengantar Ilmu Pariwisata. Yogyakarta: ANDI.

Prayogi, Putu Agus. 2012. Faktor-Faktor yang Mempengaruhi Komodifikasi Tema Lukisan Sebagai Dampak Perkembangan Pariwisata di Ubud. Jurnal. Perhotelan dan Pariwisata, STIPAR Triatma Jaya. 
Suarthana, I Ketut Putra. 2015. “Dampak Partisipasi Masyarakat Dalam Pengelolaan Desa Wisata Terhadap Sosial Budaya, Lingkungan, Dan Ekonomi: Kajian Komparatif Antara Desa Wisata Bedulu, Bali Dan Pentingsari, Yogyakarta" (disertasi). Denpasar: Universitas Udayana.

Tosun, Cevat. 2006. Expected Nature of Community Participation in Tourism Development. Jurnal. Turkey: School of Tourism and Hotel Management, Mustafa Kemal University.

Wiyasnawa, I Made Puji. 2018. "Partisipasi Masyarakat Lokal Dalam Pengembangan Desa Wisata Bayung Gede, Kecamatan Kintamani, Kabupaten Bangli" (skripsi). Denpasar: Universitas Udayana.

\section{Profile Penulis}

I Wayan Windutama, S.ST.Par., lahir di Dsn. Pamesan 12 April 1994 adalah mahasiswa program studi Magister Pariwisata, Fakultas Pariwisata, Universitas Udayana. Sebelumnya menyelesaikan program sarjana di Jurusan Diploma IV Pariwisata, Fakultas Pariwisata, Universitas Udayana pada tahun 2016 dengan gelar yang didapat yakni S.ST.Par. Saat ini penulis bekerja sebagai guru perhotelan di SMK Negeri 4 Denpasar dan SMK PGRI 3 Denpasar. Email: windhu_utama@yahoo.com.

Dr. Drs. I Nyoman Sunarta, M.Si., menyelesaikan pendidikan S1 di Fakultas Geografi Universitas Gadjah Mada (1986), S2 di Ilmu Lingkungan, Fakultas Geografi Universitas Gadjah Mada (1994) dan pendidikan S3 di Kajian Pariwisata Universitas Udayana (2015). Pernah mengikuti short course Integrated Coastal Zone Planning and Management di James Cook University Townsville, Australia tahun 1997. Pernah menjadi sekretaris PPLH Universitas Udayana 1998-2002, pada saat yang sama ditugaskan sebagai anggota tim ahli pembangunan Bali dan Kota Denpasar. Beberapa tulisannya dimuat di berbagai jurnal nasional dan internasional, Ia juga aktif berbicara dan mempresentasikan pemikirannya dalam berbagai konferensi di dalam maupun luar negeri. Pernah mengelola program Dikti Double Degree 
Indonesia Perancis S2 dan S3 bidang pariwisata di Pascasarjana Universitas Udayana. Saat ini Ia menjabat sebagai Dekan Fakultas Pariwisata Universitas Udayana periode tahun 2017-2021. Email: cairns54@yahoo.com.

Ni Made Sofia Wijaya, S.ST.Par., M.Par., Ph.D., adalah dosen program studi S1 Industri Perjalanan Wisata sekaligus program studi Magister Pariwisata, Fakultas Pariwisata, Universitas Udayana. Menyelesaikan pendidikan Diploma IV di Universitas Udayana Denpasar pada tahun 2003. Pada tahun 2007-2009, Ia mengikuti Program Pascasarjana Universitas Udayana. Di tahun 2007, Ia mengikuti short course program International Degree Program in Tourism Management (ISTM) di University Apllied Sciences, Hochschule, Bremen. Kemudian menyelesaikan studi di Program Doktor di Yamaguchi University, Jepang. Email: mdsofiawij@gmail.com. 